UDC $371.3:: 811.133 .1243$

DOI 10.18485/primling.2015.16.11

\author{
Lidija Pasuljević \\ Centar za nastavu stranih jezika, Zadužbina Ilije M. Kolarca
}

\title{
DVOJEZIČNA NASTAVA NA FRANCUSKOM JEZIKU U SRBIJI: ISTRAŽIVANJE RECEPTIVNIH VEŠTINA UČENIKA
}

Sažetak: U ovom radu bavimo se uticajem koji CLIL tip dvojezične nastave ima na usvajanje francuskog kao stranog jezika. Ispitivali smo receptivne veštine učenika (razumevanje pročitanog teksta i zvučnog materijala) uključenih u CLIL i njihove rezultate uporedili sa učenicima jednojezičnih odeljenja. Istraživanje smo sproveli u drugom razredu Treće beogradske gimnazije. Učenici su radili test za pripremu ispita Delf B1 Junior Scolaire. Rezultati istraživanja pokazuju da su učenici dvojezičnog odeljenja uspešno savladali test i da vladaju B1 nivoom receptivnih veština. Takođe, učenici iz dvojezičnog odeljenja postigli su bolji uspeh u odnosu na učenike iz jednojezičnih odeljenja, posebno na testu usmene recepcije.

Ključne reči: Dvojezično/bilingvalno obrazovanje; CLIL nastava; francuski jezik; pisana recepcija; usmena recepcija.

\section{UVOD}

Bilingvalno ili dvojezično obrazovanje podrazumeva da se „nastava nejezičkih predmeta izvodi bar na dva jezika“, tj. da se „dva jezika koriste u nastavne svrhe“ (Skutnab- Kangas 1991: 145).

Predmet našeg rada jeste dvojezična nastava na francuskom, kao stranom, i srpskom, maternjem jeziku u Trećoj beogradskoj gimnaziji. Dvojezična nastava odvija se prema CLIL pristupu (Content and Language Integrated Learning) koji podrazumeva da se nastava jednog ili više nejezičkih predmeta odvija na dodatnom jeziku (Do Coyle et al. 2010:3). Taj jezik se naziva posrednički ili vehikolarni jezik (Vučo 2006:42), a učenje sadržaja i jezika odvija se istovremeno, jedan putem drugog. Vehikolarni jezik ujedno je i sredstvo u nastavi i poseban nastavni predmet. CLIL metoda ne zahteva da oba jezika budu podjednako zastupljena u nastavi, niti da nastavnici imaju nivo vehikolarnog jezika kao izvorni govornici.

U literaturi se navodi da programi poput CLIL-a, kada je strani jezik slabije zastupljen u nastavi, imaju za cilj da učenici dostignu funkcionalnu kompetenciju kako receptivnih tako i produktivnih veština (Muñoz 2002 u Garcìa 2009: 210).

Upravo sa ciljem da se podigne nivo jezičkih veština učenika iz stranog jezika i poboljša nivo nastavničke kompetencije, kao i da se razvija dvojezičnost u Republici Sr- 
biji i osavremeni obrazovno-vaspitni rad kroz uvođenje savremenih i efikasnijih metoda rada (Đurić 2006: 32), Ministarstvo prosvete i sporta uvelo je dvojezičnu nastavu na sprskom i francuskom, to jest italijanskom, engleskom i ruskom jeziku školske 2004/2005. godine.

Dvojezična nastava na francuskom jeziku prisutna je u gimnazijama u Beogradu, Novom Sadu, Sremskim Karlovcima, Nišu, Pirotu i Valjevu, kao i u OOŠ „,Vladislav Ribnikar" u Beogradu. U školskoj 2013/2014. godini u nastavu je bilo uključeno 69 nastavnika, od toga 20 nastavnika francuskog jezika i 49 nejezičkog predmeta koji su radili sa ukupno 423 učenika ${ }^{1}$.

Bilingvalna nastava organizovana je na sledeći način: „Učenici prate nastavu na francuskom jeziku u obimu najmanje $30 \%$, a najviše $45 \%$ od ukupnog fonda časova na godišnjem nivou. Nastavni predmeti koji se predaju na francuskom jeziku nisu propisani. Škole se za njih opredeljuju u skladu sa kadrovskim mogućnostima.“ (Đurić 2006: 33). Kako bi započeli bilingvalno školovanje u gimnaziji učenici polažu pisani i usmeni test iz francuskog jezika, a pri upisu u gimnaziju od njih se zahteva A2 nivo jezika prema Zajedničkom evropskom referentnom okviru za žive jezike. Kada učenici polože Veliku maturu dobijaju diplomu sa napomenom o završenom dvojezičnom obrazovanju, koja ih oslobađa polaganja testova jezika pri upisu na frankofone univerzitete. Od njih se očekuje da dostignu B2 nivo jezika prema ZEROJ. S druge strane, potrebni nivo znanja jezika za predavače je između B2 i C1 (Ibid).

\section{CLIL MODEL U TREĆOJ BEOGRADSKOJ GIMNAZIJI}

Svake školske godine u Trećoj beogradskog gimnaziji upisuje se jedno dvojezično odeljenje iz francuskog i jedno iz italijanskog jezika.

U školskoj 2013/2014. godini u prvom razredu francuske sekcije dvojezične nastave upisano je 34 učenika, u drugom razredu 24 učenika, u trećem 23 i u četvrtom razredu 24 učenika. Broj nastavnika nejezičkog predmeta koji učestvuje u dvojezičnoj nastavi i predaje na srpskom i francuskom jeziku je 10, dok su u nastavu uključena 2 nastavnika francuskog jezika². Učenici su tokom 2013/2014. godine nastavu delimično na francuskom jeziku pratili iz hemije, fizike, biologije, likovne i muzičke kulture, istorije, geografije, matematike i filozofije. Pored zvaničnog udžbenika na srpskom jeziku učenici koriste dodatne materijale iz francuskih udžbenika koje obezbeđuje predmetni nastavnik. Što se francuskog jezika tiče, udžbenik koji se koristi u nastavi je isti kao i u jednojezičnim odeljenjima, Belleville $2^{3}$ (prvi i drugi razred) ili Belleville $3^{4}$ (treći i četvrti razred) u izdanju CLE International. Međutim, dvojezična odeljenja od drugog do četvrtog razreda imaju veći fond časova nedeljno, odnosno tri, pet i četiri, kao i po jedan čas nedeljno sa stranim lektorom.

U ovom radu istraživali smo da li učenici dvojezičnog odeljenja drugog razreda Treće beogradske gimnazije postižu očekivani napredak u vladanju francuskim jezikom

1 Interni podaci Francuskog instituta u Srbiji za školsku 2013/2014.godinu. Podatke nam je ljubazno ustupila Elisabeth Juin, koordinatorka za dvojezičnu nastavu Francuskog Instituta 2014.godine.

2 Interni podaci Francuskog instituta u Srbiji za školsku 2013/2014.godinu.

3 Gallier, T., Grand-Clément, O. (2004). Belleville 2. Paris : Cle International/Sejer.

4 Grand-Clément, O. et al. (2005). Belleville 3. Paris : Cle International/Sejer. 
od trenutka kada su započeli svoje školovanje. Takođe, kako bismo utvrdili u kojoj meri CLIL pristup utiče na usvajanje francuskog jezika, testirali smo receptivne veštine učenika dvojezičnih odeljenja i njihove rezultate uporedili sa učenicima jednojezičnih odeljenja iste gimnazije.

Odabrali smo učenike drugog razreda kao uzorak za istraživanje budući da su učenici tada dovoljno vremema proveli u dvojezičnoj nastavi i da su se navikli na program i metode rada u nastavi, a kako su i na polovini svog školovanja u gimnaziji, možemo testirati njihov napredak u učenju francuskog kao stranog jezika.

\section{OPIS ISTRAŽIVANJA}

Budući da je traženi nivo za upis u dvojezično odeljenje u gimnaziji A2, a da se od učenika na kraju četvrtog razreda očekuje da dostignu B2 nivo prema ZEROJ, testirali smo da li su učenici na kraju drugog razreda dostigli nivo B1. Za potrebe ovog istraživanja ispitivali smo receptivne veštine učenika, pisanu i usmenu. Koristili smo primer testa za pripremu za polaganje međunarodnog ispita DELF, nivoa B1 za juniore, Delf junior scolaire B1 200 activités $^{5}$, koji po temama odgovara njihovom uzrastu.

Učenici su test pisane recepcije radili 30 minuta. Test sadrži 9 pitanja (dva zadatka zatvorenog i jedan otvorenog tipa) vezana za pisani, autentični dokument novinskog tipa sa temom „Vaspitna uloga dnevnih novina“. Od kandidata se očekuje da razume šta korišćenje štampe u nastavi razvija, izaziva i favorizuje. Dati su zadaci u kojima treba označiti jedan tačan od ponuđena tri odgovora, da odrede da li je iskaz tačan/netačan/ne zna se i da dopune odgovore. Svaki tačan odgovor na pitanje bodovali smo jednim poenom.

Test usmene recepcije učenici su radili 20 minuta. I ovaj test takođe sardži 9 pitanja, a od kandidata se očekivalo ili da dopune odgovore ili da označe jedan tačan od ponuđena tri odgovora. Tema zvučnog dokumenta je istorijat Luvra, kraljevske plalate i muzeja. Za svaki tačan odgovor učeniku je bio dodeljen po jedan poen.

U istraživanju koje je sprovedeno tokom maja 2014. godine učestvovalo je ukupno 66 učenika na testu pisane recepcije $\mathrm{i}$ isto toliko na testu usmene recepcije. Kao uzorak pored dvojezičnog odeljenja II4f uzeli smo i dva jednojezična odeljenja (uzeta su dva odeljenja jer se učenici dele na one koji uče francuski ili ruski/nemački jezik).

Budući da su testovi rađeni tokom dva dana nije isti broj učenika po odeljenjima učestvovao u izradi oba dela testa i konačan broj izgleda ovako:

\begin{tabular}{|c|c|c|c|c|c|c|}
\hline \multirow{2}{*}{ Odeljenje } & \multicolumn{2}{|c|}{ Pisana recepcija } & \multirow{2}{*}{ Ukupno } & \multicolumn{2}{|c|}{ Usmena recepcija } & \multirow{2}{*}{ Ukupno } \\
\cline { 2 - 3 } & Broj devojčica & Broj dečaka & & Broj devojčica & Broj dečaka & \\
\hline II1 & 13 & 6 & 19 & 15 & 5 & 20 \\
\hline II7 & 7 & 12 & 19 & 7 & 10 & 17 \\
\hline II4f & 21 & 7 & 28 & 22 & 7 & 29 \\
\hline
\end{tabular}

Tabela 1. Broj učenika po odeljenjima koji su učestvovali u istraživanju

5 Uvid u test je moguć putem sledeće reference: Rausch, A. et al. (2006). Delf junior scolaire B1 200 activités. Paris: Cle International. pp. 18, 107. 
Pored razlike u broju učesnika istraživanja iz jednojezičnih i dvojezičnih odeljenja, važno je napomenuti, zbog postignuća na testovima i analize rezultata, još jednu značajnu razliku u uzorku. Učenici su zamoljeni da na testu naglase koliko godina uče francuski jezik, i da li su pohađali OOŠ ,Vladislav Ribnikar“, gde se francuski jezik uči od prvog razreda sa nedeljnim fondom od 6 časova ${ }^{6}$. To predstavlja veliku prednost u učenju jezika u odnosu na sve ostale beogradske osnovne škole, gde prema nastavnom planu učenici imaju 2 časa francuskog jezika na nedeljnom nivou?

U dvojezičnom odeljenju II4f , 76\% učenika pohađalo je OOŠ „Vladislav Ribnikar". Osim toga, u kratkoj anketi, jedna učenica je navela da smatra francuski svojim maternjim jezikom, dok je dvoje učenika obrazovanje na nivou osnovne škole steklo u frankofonim zemljama. Može se očekivati da ove dve varijable utiču i na postizanje boljih rezultata u našem istraživanju.

Sa druge strane, u jednojezičnim odeljenjima nijedan učenik se nije izjasnio da mu je maternji jezik francuski kao ni da je obrazovanje na nivou osnovne škole stekao u inostranstvu. Deset učenika pohađalo je OOŠ „Vladislav Ribnikar“ (26\% uzorka).

$\mathrm{U}$ nastavku rada prikazaćemo rezultate testiranja pisane, a potom i usmene recepcije učenika. Vodeći se kvantitativnom metodom, analiziraćemo sledeće: broj poena koji su učenici ostvarili, prosečan zabeležen broj poena i koliko je učenika ostvarilo broj poena ispod 5 poena (što je nešto više od polovine od maksimalnog broja poena), to jest 5 poena ili više. Radi dobijanja što preciznijih i verodostojnih rezultata poređenja postignuća učenika iz jednojezičnih i dvojezičnog odeljenja, poredićemo njihove rezultate imajući u vidu specifičnosti uzorka. Stoga ćemo rezultate dvojezičara koji su pohađali OOŠ „Vladislav Ribnikar“ uporediti sa jednojezičarima iz iste osnovne škole. Takođe ćemo međusobno uporediti rezulate učenika iz jednojezičnih i dvojezičnog odeljenja koji nisu pohađali pomenutu osnovnu školu.

\section{REZULTATI ISTRAŽIVANJA PISANE RECEPCIJE}

Kako smo prethodno napomenuli, maksimalan broj poena na testu pisane recepcije bio je 9 poena.

Rezultati izgledaju ovako:

6 Izvor : http://os-ribnikar.edu.rs/francuski-jezik

7 Nastavni plan od prvog do četvrtog razreda: http://www.zuov.gov.rs/dokumenta/CRPU/Osnovne $\% 20$ skole $\% 20$ PDF/Prvi\%20ciklus\%20osnovnog\%20obrazovanja $\% 20 \mathrm{i} \% 20$ vaspitanja/ $\% 20$ Nastavni $\% 20$ plan.PDF

Nastavni plan od petog do osmog razreda:

http://www.zuov.gov.rs/dokumenta/CRPU/Osnovne\%20skole\%20PDF/Drugi\%20ciklus\%20osnovnog\%20obrazovanja\%20i\%20vaspitanja/1\%20Nastavni\%20plan\%20za\%20drugi\%20ciklus\%20osnovnog\%20obrazovanja\%20i\%20vaspitanja.pdf 


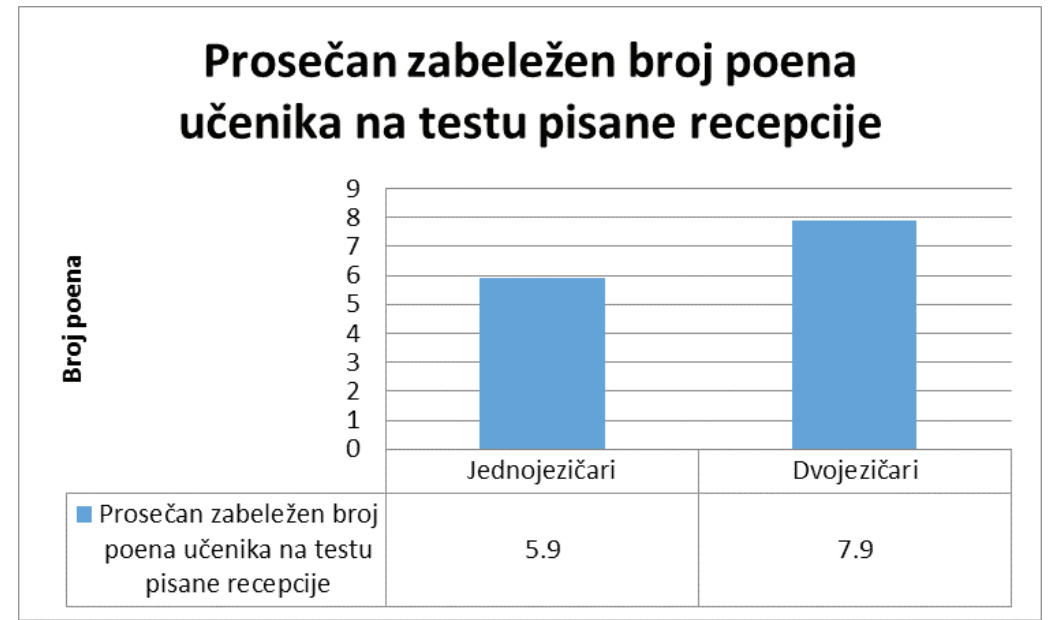

Grafikon 1.1. Uspeh učenika na testu pisane recepcije

Kako je prikazano na grafikonu, gledano uopšteno, bolji rezultat na testu postigli su učenici dvojezičnog odeljenja.

Razlika u uspehu na testu može se jasnije videti ukoliko uporedimo koliko je učenika imalo ispod 5 poena, odnosno 5 ili više poena, iz dvojezičnog i jednojezičnih odeljenja.

I prema ovim podacima, učenici uključeni u CLIL nastavu postigli su bolji uspeh na testu, budući da su svi učenici postigli rezultat u rasponu od 5 ili više poena. Sa druge strane, na sledećem grafikonu vidi se učinak jednojezičara:

\section{Uspeh jednojezičara na testu pisane recepcije}

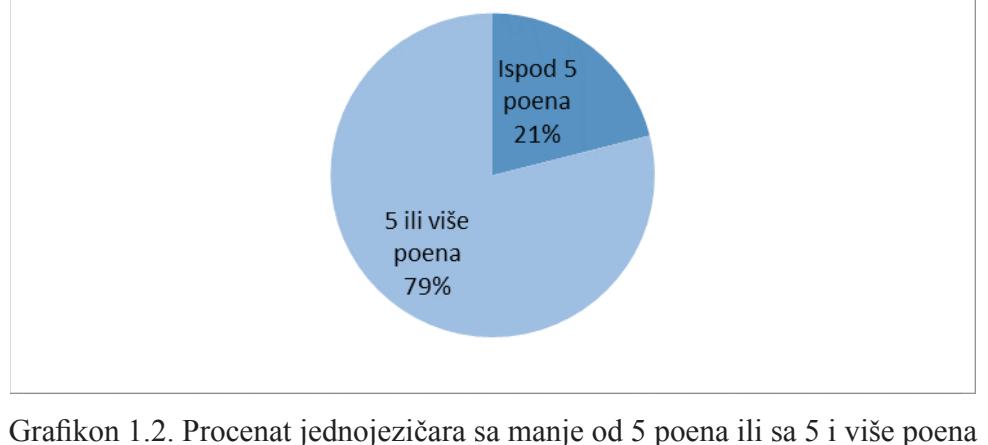

Imajući u vidu prethodno pomenutu specifičnost uzorka, uporedićemo, odvojeno, rezultate učenika iz jednojezičnih i dvojezičnog odeljenja koji su prethodno pohađali OOŠ „Vladislav Ribnikar“, kao i međusobno rezultate onih koji to nisu. 
U prvoj podgrupi uzorka test je radio 21 učenik iz II4f i ukupno 8 učenika iz odeljenja II1 i II7. Rezultati ovog dela uzorka mogu se videti na grafikonu 1.3.

\section{Prosečan zabeležen rezultat učenika iz OOŠ "Vladislav Ribnikar" na testu pisane recepcije}

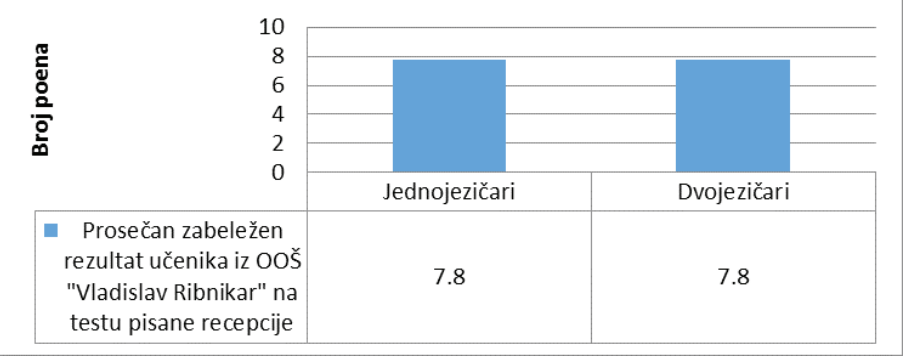

Grafikon 1.3. Uspeh učenika na testu pisane recepcije koji su pohađali OOŠ „Vladislav Ribnikar“

Rezultati pokazuju da su se učenici iz jednojezičnih i dvojezičnog odeljenja u ovoj podgrupi uzorka dobro snašli na testu i postigli jednak prosečan broj poena. Treba, međutim, pomenuti i pojedine razlike. Najmanji zabeležen broj poena na ovom delu testa učenika jednojezičnih odeljenja bio je 7 poena, kao i kod njihovih vršnjaka iz II4f odeljenja. Sa druge strane, najviši zabeležen broj poena kod jednojezičara, koji su postigle dve učenice, bio je maksimalnih 9 poena, dok je u dvojezičnom odeljenju isti skor zabeležilo čak 7 učenika.

Treba istaći i rezultate naše druge podgrupe, a to su učenici koji su pohađali druge osnovne škole, gde su učili francuski jezik od 3. ili 5. razreda. Ovaj deo uzorka je potencijalno i interesantniji za analizu učinka dvojezične nastave u procesu usvajanja stranog jezika, jer se vidi direktniji uticaj same nastave, bez intenzivnog uranjanja u jezik pre ulaska u CLIL. U ovoj podgrupi imamo 4 učenika iz II4f odeljenja i 30 učenika iz II1 i II7.

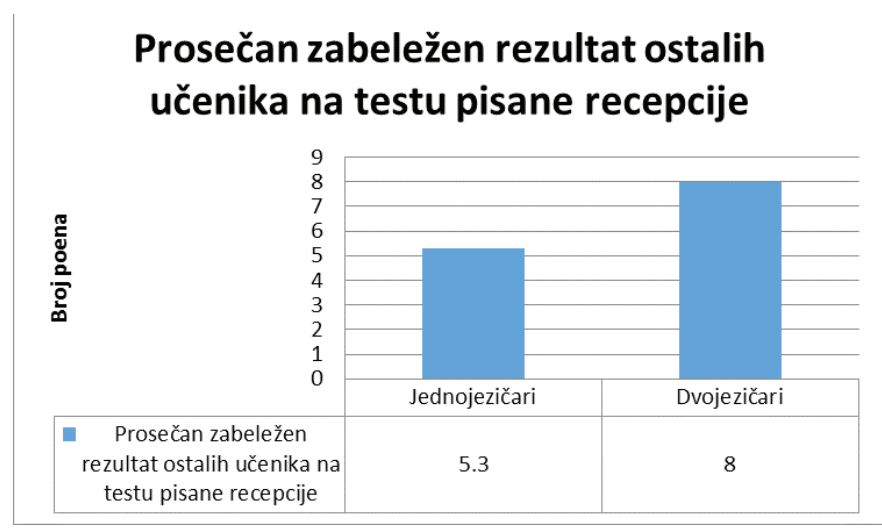

Grafikon 1.4. Uspeh učenika na testu pisane recepcije koji nisu pohađali OOŠ „Vladislav Ribnikar“ 
Prikupljeni podaci pokazuju da su učenici uključeni u CLIL postigli za 2.7 bodova veći prosečan rezultat. Njihov ujedno najniži i najviši skor bio je prilično visok i ujednačen, 8 poena od 9 , koliko su sva 4 učenika postigla, dok je situacija kod jednojezičara drugačija i varira. Najniži broj poena jednojezičara bio je 0 poena, koliko je zabeležio jedan učenik (njih troje je imalo po 1 poen), dok je njihov najviši rezultat bio 8 poena, koliko je zabeležilo deset učenika, od ukupno 30.

Uspeh troje učenika II4f odeljenja posmatrali smo izdvojeno, budući da nismo imali odgovarajući uzorak za poređenje u jednojezičnim odeljenjima. Dvoje učenika iz II4f odeljenja koji su se školovali u inostranstvu na francuskom jeziku, zabeležili su 8, to jest 9 poena, a učenica koja smatra francuski jezik svojim maternjim je, očekivano, imala maksimalnih 9 poena.

Greške koje su se javljale na testu kod dvojezičara bile su vezane za tip zadatka tačno/netačno/ ne zna se, a samo jedna učenica je pogrešila kod jednog otvorenog pitanja.

Učenici iz jednojezičnih odeljenja pravili su greške i kod zatvorenog i kod otvorenog tipa pitanja, a čak 9 učenika nije dalo odgovor ni na jedno od tri otvorena pitanja. Oni su, dakle, pored poteškoća u razumevanju teksta imali poteškoća i u slobodnom formulisanju odgovora svojim rečima.

\section{REZULTATI ISTRAŽIVANJA USMENE RECEPCIJE}

Da podsetimo, i na testu usmene recepcije maksimalan broj poena je takođe bio 9. Prosečan broj poena zabeležen na testu izgleda ovako:

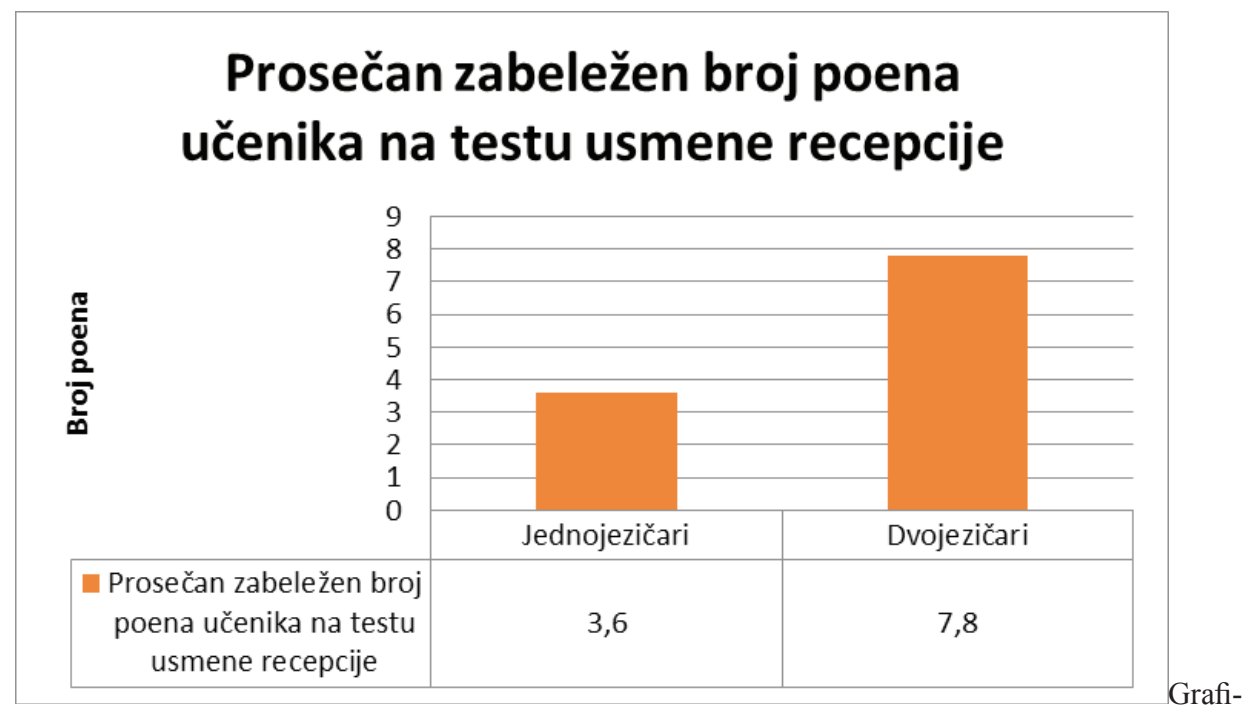

kon 2.1. Uspeh učenika na testu usmene recepcije

Kako se na grafikonu vidi, ponovo su bolji prosečan broj poena imali učenici iz dvojezičnog odeljenja, međutim ovoga puta sa većom razlikom u odnosu na jednojezična odeljenja. 
To pokazuju i sledeći grafikoni koji predstavljaju, izraženo u procentima, koliko je bilo učenika sa manje od 5 poena, odnosno sa 5 ili više poena iz dvojezičnog, i dva jednojezična odeljenja zajedno.

Uspeh dvojezičara na testu usmene recepcije

Ispod 5 poena

$3 \%$

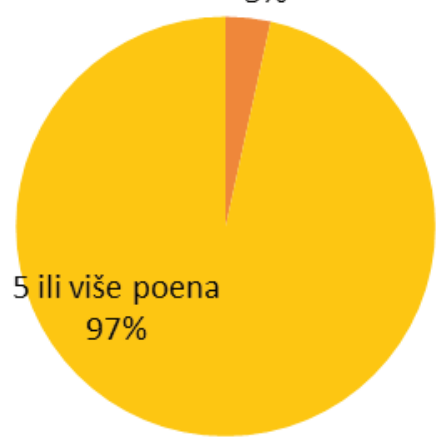

Grafikon 2.2. Procenat dvojezičara ispod 5 poena ili sa 5 i više poena

Uspeh jednojezičara na testu usmene recepcije

5 ili više

poena

$35 \%$

Ispod 5

poena

$65 \%$

Grafikon 2.3. Procenat jednojezičara ispod 5 poena ili sa 5 i više poena

138 
I prema ovim podacima učenici iz bilingvalnog odeljenja postigli su bolji uspeh na testu, $97 \%$ učenika sa 5 ili više zabeleženih poena, prema $65 \%$ učenika iz jednojezičnih odeljenja.

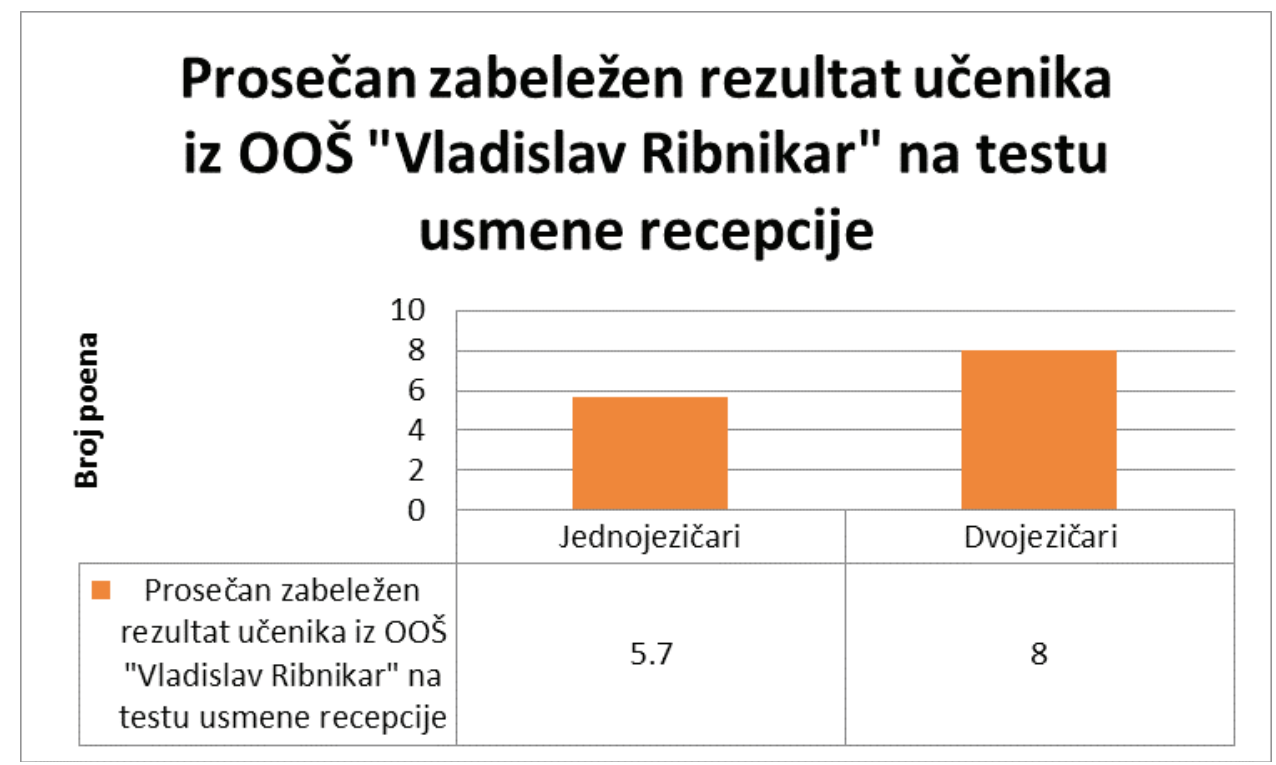

Grafikon 2.4. Uspeh učenika na testu usmene recepcije koji su pohađali OOŠ „Vladislav Ribnikar“

U podgrupi učenika iz OOŠ ,, Vladislav Ribnikar“ iz bilingvalnog i jednojezičnih odeljenja test je radio 21 učenik iz II4f odeljenja, odnosno ukupno 10 učenika iz odeljenja II1 i II7.

Prema prikupljenjim podacima, učenici uključeni u CLIL postigli su bolje rezultate od njihovih vršnjaka iz jednojezičnih odeljenja, i to za 2.3 poena. Kada rezultate pogledamo nešto detaljnije, kod jednojezičara je najmanji broj poena bio 2 poena, koliko je zabeležila jedna učenica, a najviši broj poena bio je 8 poena, koliko je imalo osmoro učenika. Kod učenika iz dvojezičnog odeljenja najmanji broj poena bio je 4 poena, što je zabeleženo kod jedne učenice, dok je deset učenika imalo najviši postignut broj poena, ujedno i maksimalan, 9.

Slična situacija sreće se i u drugoj podgrupi učenika koji nisu pohađali pomenutu osnovnu školu. U ovom delu uzorka test je radilo 5 učenika iz dvojezičnog, odnosno 27 učenika iz jednojezičnih odeljenja. 


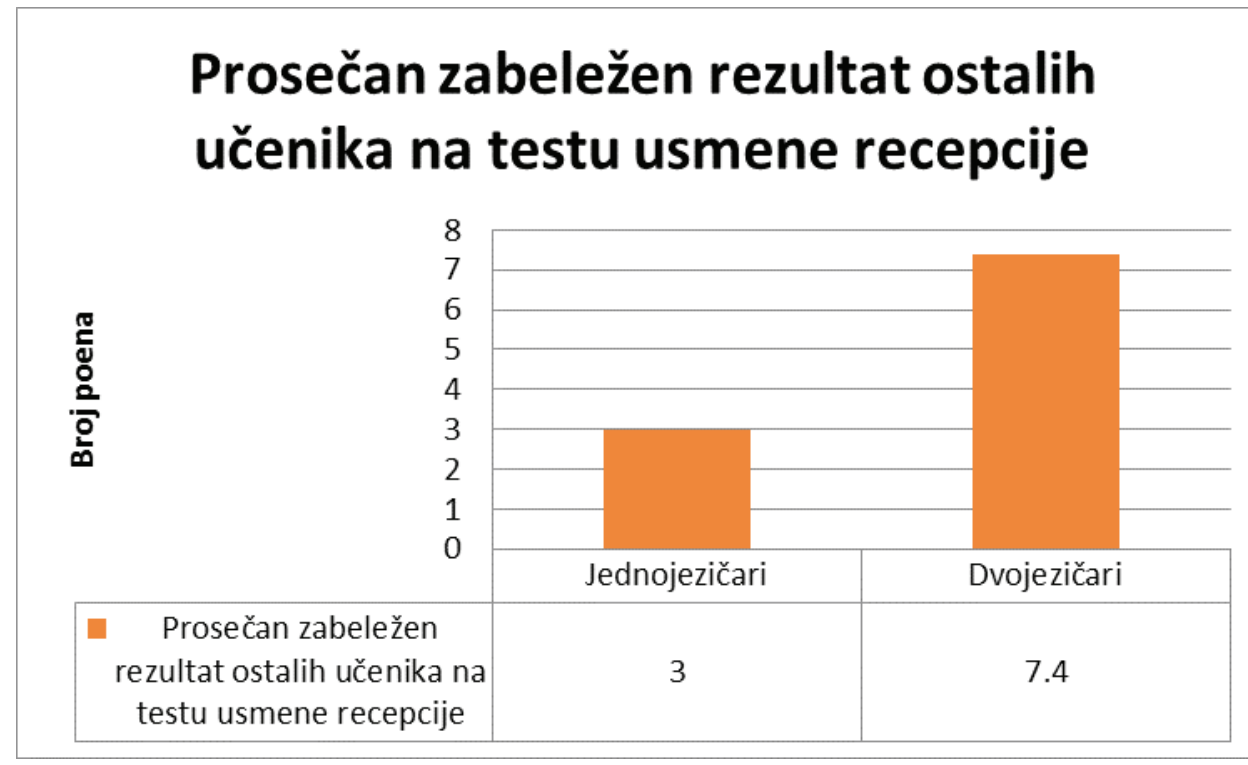

Grafikon 2.5. Uspeh učenika na testu usmene recepcije koji nisu pohađali OOŠ "Vladislav Ribnikar"

I u ovoj podgrupi, učenici iz dvojezičnog odeljenja postigli su ubedljivo bolji prosečan broj poena na testu. Njihov najmanji broj poena, koliko je zabeležila jedna učenica, bio je 5, dok je najviši broj poena bio 8 koliko su postigle dve učenice od njih petoro. Sa druge strane, kod jednojezičara je najmanji broj poena zabeležila jedna učenica i iznosi 0 poena, petoro učenika je imalo svega 1 poen, a maksimalan broj poena bio je 7, koliko su imala dva učenika.

Tri učenika iz II4f odeljenja, koje smo posmatrali odvojeno jer su se školovali u inostanstvu ili im je francuski ujedno i maternji jezik, postigli su maksimalnih 9 poena.

Kada je reč o tipičnim greškama, treba napomenuti da je na pitanju koje je jednojezičarima zadavalo najveći problem, gde je trebalo napisati koje godine je Luvr osnovan, samo 6 učenika odgovorilo tačno, to jest svega 15\% uzorka, od toga četvoro iz prve podgrupe. Trideset učenika nije dalo tačan odgovor među kojima je bilo četrnaest koji su ostavili prazan odgovor. Dvojezičari su, ne računajući tri izdvojena učenika, zauzvrat, zabeležili samo tri netačna odgovora na ovo pitanje, odnosno imamo dvadeset tri tačna odgovora, što predstavlja 79\% uzorka. Takođe, jednojezičari su pravili greške i kod pitanja gde je trebalo zaokružiti jedan tačan od tri ponuđena odgovora kao i kod pitanja na dopunjavanje brojevima, dok su dvojezičari pravili greške samo kod drugog tipa pitanja.

\section{ZAKLJUČAK}

Sudeći po dobijenim rezultatima istraživanja, možemo izvući tri glavna zaključka.

Učenici uključeni u CLIL postigli su napredak u učenju francuskog jezika očekivanim tempom i uspešno se snalaze na B1 nivou kada je o receptivnim veštinama reč, što 
dokazuje veoma visok prosečan broj poena na testovima, 7.9 na testu pisane i 7.8 na testu usmene recepcije. Najmanji broj poena na testu pisane recepcije bio je ubedljivih 7 poena, dok je najmanji broj poena na testu usmene recepcije bio 4 od maksimalnih 9. Njihovi rezultati su takođe prilično ujednačeni. I učenici koji nisu pohađali OOŠ „Vladislav Ribnikar“ imali su jako visok učinak, kao i učenici drugih osnovnih škola koji su bili manje izloženi francuskom jeziku pre ulaska u CLIL. To svedoči i o uspešnosti sprovođenja CLIL nastave.

Kako se iz rezultata testova vidi, učenici iz dvojezičnog odeljenja postigli su bolje rezultate u odnosu na vršnjake iz dva jednojezična odeljenja, osim na testu pisane recepcije gde su učenici u prvoj podgrupi, iz OOŠ “Vladislav Ribnikar", zabeležili isti prosečan broj poena kao i učenici iz jednojezičnih odeljenja iz iste osnovne škole. Još uočljivija razlika u uspehu na testovima prisutna je u drugoj podgrupi kod učenika koji su francuskom jeziku bili manje izloženi tokom osnovne škole, gde je razlika u prosečnom zabeleženom broju poena u korist dvojezičara 2.7 bodova na testu pisane recepcije prema čitavih 4.4 na testu usmene recepcije. Naše istraživanje je, dakle, pokazalo da su dvojezičari daleko bolje snalaze u usmenoj recepciji od vršnjaka iz jednojezičnih odeljenja. Takav rezultat možemo upravo tumačiti kao zaslugu predavanja nejezičkog predmeta na francuskom jeziku, te učenici imaju naviku da prate usmeno izlaganje na stranom jeziku i njemu su duže i više izloženi.

Za razliku od dvojezičara koji su na oba testa imali prilično ujednačene rezultate, kod jednojezičara su rezultati varirali. Na oba testa bilo je učenika sa nula, jednim ili dva poena, te uprkos činjenici da se većina učenika dobro snašla na testovima za B1 nivo, ne možemo reći da su svi učenici postigli B1 nivo receptivnih veština.

Kada se osvrnemo na greške, testovi su pokazali da su se dvojezičari na testu pisane recepcije bolje snašli kod otvorenog tipa pitanja u odnosu na jednojezičare, kao i da su se podjednako dobro snašli i kod zatvorenog tipa pitanja i pitanja sa popunjavanjem na testu usmene recepcije, dok je većina učenika iz jednojezičnih odeljenja imala poteškoća u oba slučaja.

\section{Literatura}

Coyle, D. et al. (2010). CLIL: Content and Language Integrated Learning. Cambridge: Cambridge University Press.

Đurić, Lj. (2006). Ogledi i inovativni projekti u nastavi francuskog jezika. In: Inovacije u nastavi stranih jezika (A. Vujović, ed.), Beograd: Učiteljski fakultet, 28-44.

Garcìa, O. (2009). Bilingual Education in the 21st Century: A Global Perspective. Oxford: John Wiley\& Sons Ltd.

Skutnab- Kangas, T. (1991). Bilingvizam da ili ne. Beograd: Zavod za udžbenike i nastavna sredstva.

Vučo, J. (2006). U potrazi za sopstvenim modelom bilingvalne nastave. In: Inovacije $u$ nastavi stranih jezika (A.Vujović, ed.), Beograd: Učiteljski fakultet, 41-54. 


\section{Lidija Pasuljević}

\section{BILINGUAL EDUCATION BASED ON THE CLIL MODEL IN SERBIA: RESEARCH IN THE DOMAIN OF STUDENTS' RECEPTIVE SKILLS}

Summary: The aim of the present paper is to examine the impact of the CLIL programme in Serbian High School on students' language proficiency in the French language. Receptive language skills (comprehension of reading and listening) of the second-year students involved in CLIL at the Third High School in Belgrade are examined. Since students are expected to reach B2 language level of the CEFR at the end of their fourth and last year, we tested second-year students' French skills on the Delf B1 Junior Scolaire preparation test. The control group consists of the Third High School's students following foreign language instruction in a traditional school context. Quantitative analysis is used for the analysis of student's results on both tests. The results show that, firstly, CLIL students passed the B1 CEFR level preparation test, and secondly, that they achieved better results than non-CLIL students, especially on the listening comprehension test.

Key words: Bilingual education; CLIL; French language; reading language skills; listening language skills. 